nificant Citrus pollinating agent (Frost and Soost, 1968). Mature fruit were harvested, and seeds were extracted and germinated in a greenhouse.

Isozyme analysis was used to confirm hybridity of the seedlings produced. Leaves were collected from 4-month-old greenhouse-grown seedlings, frozen in liquid nitrogen, and powdered with a mortar and pestle. Cold (4C) extraction buffer $(50 \mathrm{~mm}$ Tris $\cdot \mathrm{HCl} \mathrm{pH} 8.4$, $150 \mathrm{~mm} \mathrm{NaCl}, 1 \mathrm{~mm} \mathrm{CaCl}_{2}, 1 \%$ insoluble polyvinylpolypyrrolidone) was mixed with the leaf powder $(0.5 \mathrm{ml}$ buffer per $0.1 \mathrm{~g}$ leaf tissue) and stirred for $15 \mathrm{~min}$. This mixture was filtered through cheesecloth, and the filtrate was centrifuged for $20 \mathrm{~min}$ at 20,000 $\mathrm{x} g$. The supernatant was collected, and the proteins were precipitated in $50 \% \mathrm{v} / \mathrm{v}$ acetone $/ \mathrm{dH}_{2} \mathrm{O}$ (assuming additive volumes) at $-20 \mathrm{C}$ for $1 \mathrm{~h}$. Precipitated proteins were freeze-dried and stored at $-20 \mathrm{C}$. Proteins were resuspended in gel buffer $\left(50 \mu \mathrm{g} . \mu \mathrm{l}^{-1}\right)$ with $10 \% \mathrm{v} / \mathrm{v}$ glycerol and $0.0002 \% \mathrm{w} / \mathrm{v}$ bromophenol blue as the tracking dye, and loaded onto the gel $(150 \mathrm{~kg} / \mathrm{lane})$. Electrophoresis was performed in a Mini-Protean II $7 \mathrm{~cm} \times 8 \mathrm{~cm} \times 0.75 \mathrm{~mm}$ slab cell (BioRad, Richmond, Calif.) using a 0.125 м Tris $\mathrm{pH} 8.8$ polyacrylamide separation gel $(8 \%$ $\mathrm{T}, 2.67 \% \mathrm{C}$ ), and cold (4C) Tris.glycine (0.025 M Tris, 0.096 м glycine, $\mathrm{pH} 8.5$ ) electrode buffer. The proteins were separated by a MacroDrive 5 automatic crossover power supply (Pharmacia LKB Biotechnology, Piscataway, N.J.) preset to $500 \mathrm{~V}, 15$ $\mathrm{mA}$, and $10 \mathrm{~W}$ before the run. Electrophoresis was stopped when the dye front reached the end of the gel or after $40 \mathrm{~min}$. Gels were stained for GOT (Torres et al., 1978) and photographed.

Anthesis and pollen dehiscence occurred 24 to $48 \mathrm{~h}$ after flower collection. Pollen freeze-dried for 2,4 , or $8 \mathrm{~h}$ failed to germinate $24 \mathrm{~h}$ after drying, but sporadic germination $(<1 \%)$ was observed in pollen freeze-dried for $1 \mathrm{~h}$. Pollen stored in anhydrous acetone for $24 \mathrm{~h}$ at $-20 \mathrm{C}$ also failed to germinate $24 \mathrm{~h}$ after treatment. Germination of oven-dried tachibana orange pollen was similar to that of fresh pollen, with $\approx 70 \%$ germination for each of the four drying times tested. Alexander's stain color contrasted well between germinated and nongerminated ovendried pollen. Pollen tubes stained red and empty pollen grains green. From these results, tachibana orange pollen was collected as described, oven-dried for $12 \mathrm{~h}$ (chosen from the four drying times for convenience), stored at $-20 \mathrm{C}$ over silica gel, and used to pollinate a hybrid of 'Temple' $\mathrm{x}$ 'Orlando' the following year. Frozen fresh pollen failed to germinate after 1 year and was not used.

Fifty flowers were pollinated in Spring 1989, and 36 fruit with an average of 11 seed per fruit were collected in Nov. 1989, Fifty seeds were germinated in the greenhouse, and seedlings were analyzed for GOT. Acceptable resolution was obtained by acetone precipitating the water-soluble proteins, freeze-drying, and running in PAGE with a low ionic strength compared with the Laemmli (1970) stacking gel buffer, and a high field strength of $9 \mathrm{~V} / \mathrm{cm}^{2}$. Resolution was decreased when the total protein concentration exceeded $3 \mu \mathrm{g} / \mathrm{lane}$.

Both parents produced a unique single band; the band from tachibana orange migrated faster than the 'Temple' $x$ 'Orlando' band (Fig. 1, lane 1). Hybrids of these clones should produce a three-band pattern, because GOT is a dimer capable of heterodimerization. All 50 seedlings analyzed had a threeband GOT profile, confirming their hybridity (Fig. 1, lanes 2-4). Confirmation of hybridity based on morphology was difficult because these two parents are quite similar, with no readily recognizable morphological markers to distinguish hybrid seedlings.

This work demonstrated that tachibana orange pollen can be oven-dried, stored at $-20 \mathrm{C}$, and used the following season in controlled hybridizations. C. tachibana exhibits significant cold hardiness for a Citrus sp. (Swingle and Reece, 1967) and may be useful in developing cold hardy citrus types. This technique accesses previously unavailable but potentially valuable germplasm, and may provide the means to overcome the problem of asynchronous flowering with other genetically valuable Citrus selections.

\section{Literature Cited}

Alexander, M.P. 1980. A versatile stain for pollen fungi, yeast and bacteria. Stain Technol. 55:1318

Barrett, H.C. and A.M. Rhodes. 1976. A numerical taxonomic studv of affinity relationships in cultivated Citrus and its close relatives. Systematic Bot. 1:105-136.

Frost, H.B. and R.K. Soost. 1968. Seed reproduction: development of gametes and embryos, p. 298. In: W. Reuther. L.D. Batchelor, and H.J. Webber (eds.). The citrus industry vol. II. Univ. of California, Berkeley.

Laemmli, U.K. 1970. Cleavage of structural proteins during the assembly of the head of bacteriophage T4. Nature (London) 227:680-68.5.

Sahar, N. and P. Spiegel-Roy. 1980. Citrus pollen storage. HortScience 15:81-82.

Swingle, W.T. and P.C. Reece. 1967. The botany of citrus and its wild relatives, p. 385 . In: W. Reuther, H.J. Webber, and L.D. Batchelor (eds.). The citrus industry vol. I. Univ. of California, Berkeley.

Torres, A.M., R.K. Soost, and U. Diedenhofen. 1978. Leaf isozymes as genetic markers in citrus. Amer. J. Bot. 65:869-881.

HoRTSCIENCE 27(1):44-47. 1992.

\title{
DNA Restriction Fragment Length Variability in the Genomes of Highbush Blueberry
}

\author{
K. Haghighi and J.F. Hancock \\ Department of Horticulture, Michigan State University, East Lansing, \\ MI 48824
}

Additional index words. RFLPs, Vaccinium darrowi, V. ashei, V. corymbosum, V. angustifolium

Abstract. Restriction fragment analyses of chloroplast DNA (cpDNA) and mitochondrial DNA (mtDNA) were carried out on the principal cytoplasms of northern highbush cultivars and one representative of Vaccinium ashei Reade. Twenty-three restriction enzymes were used to identify variation and clarify mode of organelle inheritance. All species and genotypes displayed identical cpDNA fragment patterns, but high degrees of polymorphism were observed in the mitochondrial genomes. 'Bluecrop' and 'Jersey' did not appear to have 'Rubel' cytoplasm as was previously believed. All hybrids contained maternal-type mtDNA.

Until recently, the germplasm base of the cultivated blueberry Vaccinium corymbosum L. was restricted and nuclear genes could be traced primarily to three wild selections (Hancock and Siefker, 1986). This situation has improved dramatically in the last few years as breeders have released several cultivars composed of complex species back-

Received for publication 8 Aug. 1990. Accepted for publication 28 Aug. 1991. The cost of publishing this paper was defrayed in part by the payment of page charges. Under postal regulations, this paper therefore must be hereby marked $a d$ vertisement solely to indicate this fact. grounds (Ballington, 1990; Lyrene, 1990). However, the cytoplasmic background of the leading cultivars grown in the northern production regions is still limited and pedigree records indicate that only four cytoplasms are represented in this material: 1) 'Brooks' and 'Rubel' of $V$. corymbosum, 2) 'North Sedgwick' lowbush of $V$. angustifolium Ait., and 3) 'Florida 4B' of $V$. darrowi Camp. (Hancock and Krebs, 1986). These selections represent a broad geographical and species range, but no attempts have been made to measure their degree of divergence. In this study, we used restriction fragment length polymorphisms (RFLPs) of mitochondrial and 


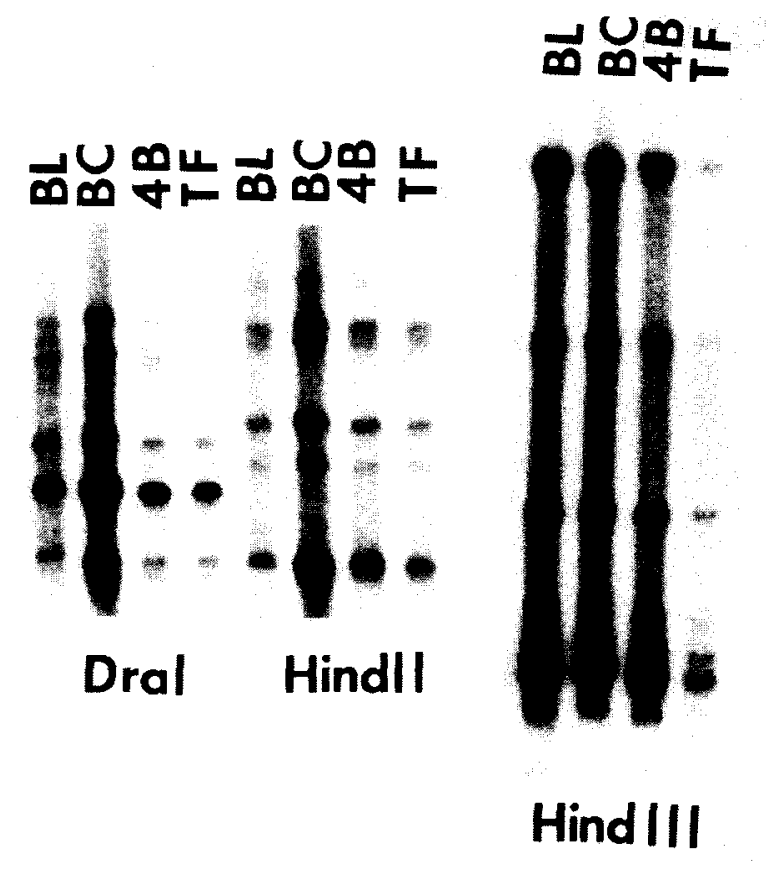

Fig. 1. Hybridization of chloroplast-specific probe of tomato (P-4) to total DNA digested with DraI, HindII, and HindIII for 'Bluetta' (BL), 'Bluecrop' (BC), 'Florida 4B' (4B), and 'Tifblue' (TF). The extra Dral band in 'Bluetta' was not present in longer digests and is assumed to be the result of incomplete digestion.

Table 1. Restriction fragment lengths of blueberry mitochondrial DNA (in kilobases) using various enzymes.

\begin{tabular}{|c|c|c|c|c|c|}
\hline \multirow[b]{2}{*}{ Plants } & \multicolumn{5}{|c|}{ Probe: $\mathrm{pZmEI}$} \\
\hline & DraI & HindIII & AvaI & MspI & RsaI \\
\hline \multicolumn{6}{|c|}{ Vaccinium corymbosum $(4 \mathrm{x})$} \\
\hline Rubel & $3.6,4.4$ & 2.7 & $1.3,1.85,9.0$ & $1.3,1.4$ & $1.4,1.6$ \\
\hline Bluecrop & $2.7,4.8$ & 3.3 & $0.8,2.8$ & $\begin{array}{r}1.0,1.3,1.6 \\
3.2,4.2,6.4\end{array}$ & $1.5,1.9,6.7$ \\
\hline Bluejay & 5.3 & 2.8 & $0.8,2.8,6.8$ & $\begin{array}{c}1.0,1.6,3.0 \\
4.2,8.7\end{array}$ & $1.4,1.6,3.0$ \\
\hline Jersey & $2.7,4.8$ & 3.3 & $0.8,2.8$ & $1.3,1.4,7.3$ & $\begin{array}{c}1.5,1.9,2.9 \\
\quad 6.4,7.8\end{array}$ \\
\hline Spartan & 5.3 & 2.8 & $1.65,2.0,6.0$ & $1.3,1.4$ & $\begin{array}{c}1.4,1.5,2.9 \\
4.9\end{array}$ \\
\hline \multicolumn{6}{|l|}{$\begin{array}{l}V . \text { angustifolium } \mathrm{x} \\
V . \text { corymbosum }\end{array}$} \\
\hline $\begin{array}{r}\text { Bluetta }(4 \mathrm{x}) \\
V . \text { darrowi }(2 \mathrm{x})\end{array}$ & 5.1 & 3.8 & $1.5,2.2$ & $3.4,4.6$ & $1.5,2.7$ \\
\hline Florida $4 \mathrm{~B}$ & $3.65,4.2$ & $2.3,4.9$ & $1.85,2.2$ & $0.95,1.6,9.3$ & $\begin{array}{c}1.5,1.9,2.4 \\
7.5,9.5\end{array}$ \\
\hline \multicolumn{6}{|l|}{ V. ashei $(6 \mathrm{x})$} \\
\hline Tifblue & $1.8,5.1$ & 3.8 & $\begin{array}{r}0.8,1.3,1.65 \\
2.0,4.6,6.2 \\
6.9,8.1,8.7\end{array}$ & $\begin{array}{c}0.95,1.3,7.7 \\
9.2\end{array}$ & $\begin{array}{c}1.6,1.9,2.4 \\
5.4,10.5\end{array}$ \\
\hline
\end{tabular}

plastid DNA to assess that variability.

RFLPs have been used as genetic markers to identify species, evaluate genetic diversity, and map genes of interest in numerous crops (Helentjaris et al., 1985, 1986; Landry et al., 1987; Osborn et al., 1987). They present heritable changes in the length of the fragments of genomic DNA arising by digestion with specific restriction enzymes. Chloroplast DNA (cpDNA) and mitochondrial DNA (mtDNA) are generally inherited maternally in angiosperms (Levings and Pring, 1976; Palmer, 1985), although there are a few reports of paternal plastid inheritance (Schumann and Hancock, 1989; Wagner et al., 1987). The gene arrangement and se- quence of cpDNA is typically highly conserved, while mtDNA can be variable depending on species (Ichikawa et al., 1989; Palmer, 1985; Timothy et al., 1979; Weissinger et al., 1983). Thus, analysis of cpDNA and mtDNA provides useful information for breeding programs and the study of phylogenetic and evolutionary relationships.

Five tetraploid highbush cultivars were evaluated: 'Bluetta', 'Bluecrop', 'Bluejay', 'Jersey', and 'Spartan'. Pedigree records indicate that 'Bluejay' and 'Spartan' carry the cytoplasm of the wild $V$. corymbosum selection 'Brooks', while 'Bluecrop' and 'Jersey' carry 'Rubel' cytoplasm (Hancock and Krebs, 1986). 'Bluetta' has the cytoplasm of the wild
$V$. angustifolium selection 'North Sedgwick lowbush. In addition, genotypes of diploid $V$. darrowi and hexaploid $V$. ashe $i$ were examined. Vaccinium darrowi was represented by the wild selection 'Florida 4B' and $V$. ashei by 'Tifblue'. Several hybrids were evaluated, including US75, an interspecific hybrid between 'Florida 4B' and 'Bluecrop' that has been extensively used in the development of highbush cultivars (Draper et al., 1982), and 15 individuals from reciprocal crosses of 'Spartan' $x$ 'Rubel' and 'Spartan' $\mathrm{x}$ 'Jersey'.

Total cell DNA was isolated from fully expanded leaves of greenhouse-grown plants by a modification of the CTAB procedure (Rogers and Bendich, 1985). Leaves were frozen in liquid nitrogen and ground to powder. The powder was thawed to room temperature and extracted in buffer $(1: 5 \mathrm{w} / \mathrm{v})$ containing $100 \mathrm{mM}$ Tris base (pH 8.0), 1.4 $\mathrm{M} \mathrm{NaCl}, 2 \mathrm{mM}$ ethylenediaminetetraacetic acid (EDTA), 2\% (w/v) hexadecyltrimethylammonium bromide (CTAB), $1 \%(\mathrm{w} / \mathrm{v})$ polyvinylpyrrolidone (PVP), 10\% (w/v) polyethylene glycol (PEG), 2\% (w/v) Na sarcosine, and $0.8 \%(\mathrm{v} / \mathrm{v})$ mercaptoethanol. The samples were incubated in a water bath at $65 \mathrm{C}$ for 1 to $2 \mathrm{~h}$. The mixture was then extracted with 24 chloroform : 1 isoamyl alcohol : 1 phenol (by volume) to remove protein and pigments before phase separation by centrifugation $(2600 \times \mathrm{x}$ for $10 \mathrm{~min})$. The upper phase, containing the DNA, was pipetted off between extractions. DNA was precipitated with two volumes of $100 \%$ ethanol $(\mathrm{EtOH})$ at $-20 \mathrm{C}$, rinsed with $75 \%$ $\mathrm{EtOH}$ to remove salt, and then $100 \% \mathrm{EtOH}$ to speed drying. The DNA pellet was dissolved in TE buffer (10 mm Tris- $\mathrm{HCl}$ and 1 mM EDTA, pH 8.0) and further purified on cesium chloride/ethidium bromide gradients (Maniatis et al., 1982).

DNA $(4 \mu \mathrm{g})$ from each plant was digested with the following 23 enzymes: AvaI, BamHI, BclI, BglI, BglII, CfoI, ClaI, DdeI, DraI, EcoRI, EcoRV, HindII, HindIII, KnpI, PstI, PvuI, RsaI, SalI, ScaI, SmaI, SspI, SstI, and XhoI as recommended by the supplier (Boehringer Mannheim Biochemicals, Indianapolis). Restriction digests were fractionated by electrophoresis through $0.8 \%$ or $1 \%$ (w/v) agarose horizontal slab gels in TBE buffer $(0.089 \mathrm{M}$ Tris boric acid and $0.002 \mathrm{M}$ EDTA, $\mathrm{pH} 8.0$ ) at constant $2 \mathrm{~V} \cdot \mathrm{cm}^{-1}$ for 18 to $20 \mathrm{~h}$. The gel was stained with $0.5 \mu \mathrm{g} \cdot \mathrm{ml}^{-1}$ ethidium bromide (10 $\mathrm{mg} \cdot \mathrm{ml}^{-1}$ stock solution), illuminated with an ultraviolet light box and photographed with a Polaroid camera. The DNA was then transferred to nitrocellulose by the procedure of Southern (1975). After a minimum of $24 \mathrm{~h}$, the filter was baked at $80 \mathrm{C}$ for $2 \mathrm{~h}$ in a vacuum oven.

Hybridization conditions were according to Thomashow et al. (1981). The probes were labeled with ${ }^{32} \mathrm{P}$-dCTP using random oligonucleotides as primers according to Boehringer Mannheim recommendations. A 1 kilobase $(\mathrm{kb})$ pea rbcL clone (gift from $\mathrm{J}$. Palmer), and $21.8 \mathrm{~kb}(\mathrm{P}-2), 19.4 \mathrm{~kb}$ (P-4), and $18.5 \mathrm{~kb}(\mathrm{P}-5)$ tomato chloroplast PstI clones (Phillips, 1985) were used for the 


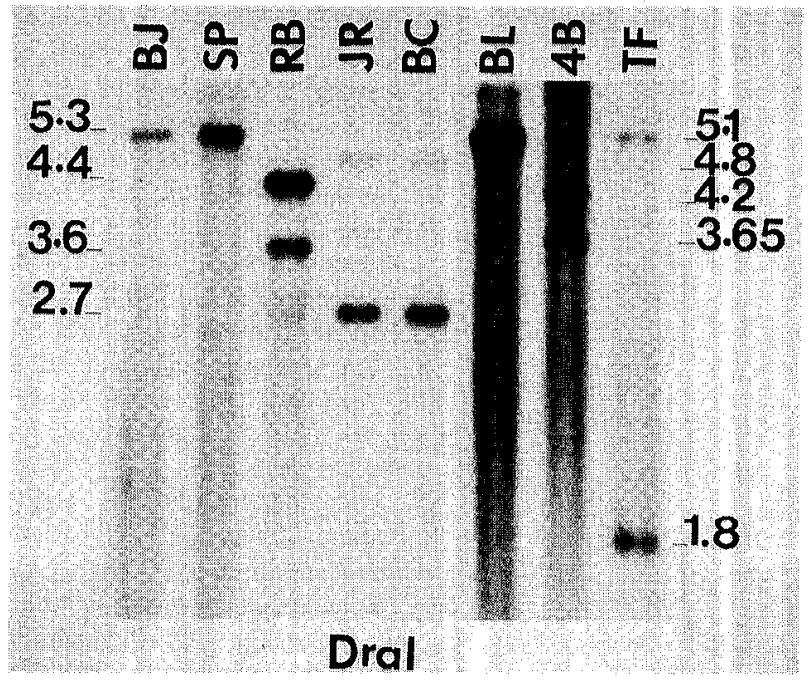

Fig. 2. Hybridization of mitochondrial probe pZmEI to DraI digests of 'Bluejay' (BJ), 'Spartan' (SP), 'Rubel' (RB), 'Jersey' (JR), 'Bluecrop' (BC), 'Bluetta' (BL), 'Florida 4B' (4B), and 'Tifblue' (TF). Fragment sizes are given in kilobases.

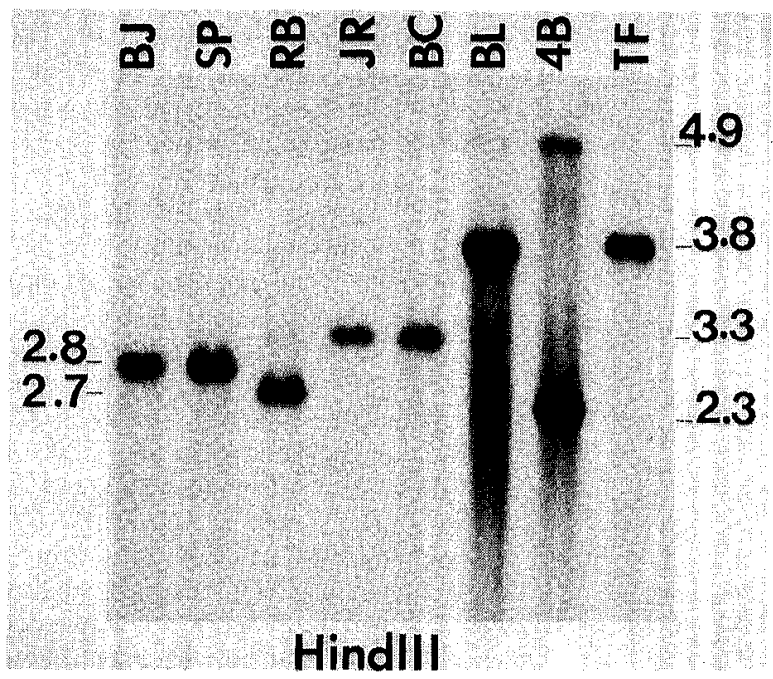

Fig. 3. Hybridization of mitochondrial probe $\mathrm{pZmEI}$ to HindIII digests of 'Bluejay' (BJ), 'Spartan' (SP), 'Rubel' (RB), 'Jersey' (JR), 'Bluecrop' (BC), 'Bluetta' (BL), 'Florida 4B' (4B), and 'Tifblue' (TF). Fragment sizes are given in kilobases.

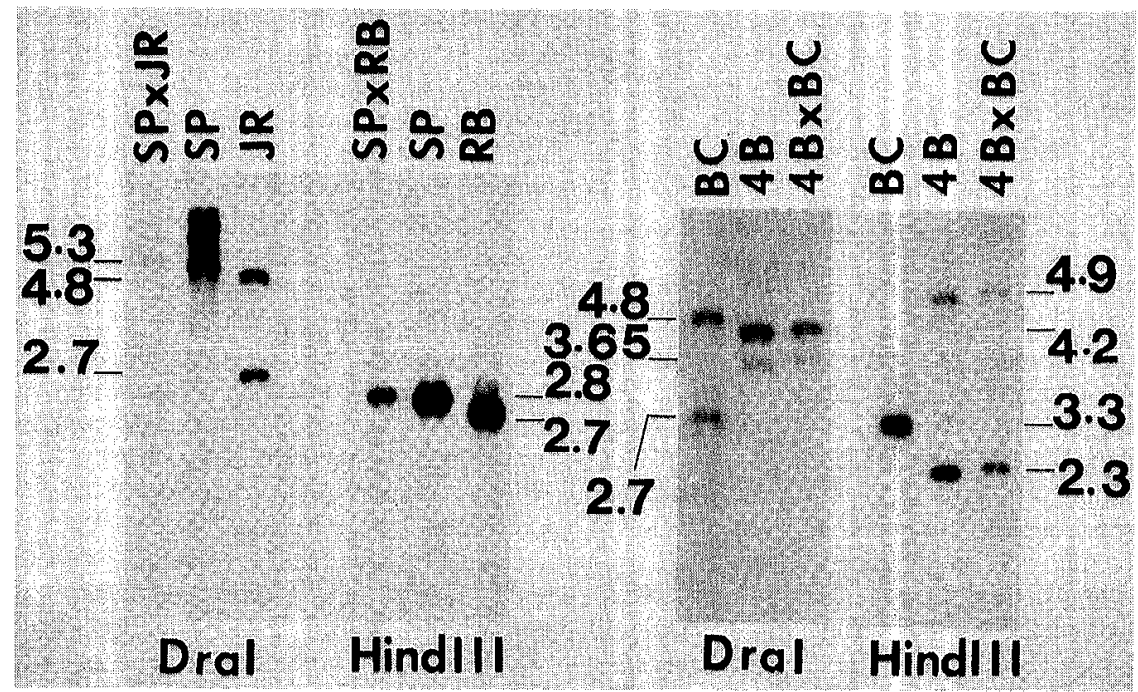

Fig. 4. Hybridization of mitochondrial probe $\mathrm{pZmEI}$ to total DNA digested with DraI and HindIII for inter- and intraspecific hybrids and parents. 'Spartan' $x$ 'Jersey' (SP X JR), 'Spartan' $x$ 'Rubel' (SP $\times R B$ ), and 'Florida 4B' $\times$ 'Bluecrop' ( $4 B \times B C)$. Maternal parent is listed first in crosses. Fragment sizes are given in kilobases, analysis of chloroplast DNA. The mtDNA was probed with pZmEI, a 2.4-kb EcoRI fragment encoding maize mitochondrial cytochrome c oxidase subunit II (Fox and Leaver, 1981; provided by B.B. Sears).

The same nitrocellulose filters were hybridized with cpDNA and mtDNA probes after removing the previous probe from the filter (Wight et al., 1986). Sizes of DNA fragments were estimated by comparison to Hind111 digests of lambda DNA.

Identical cpDNA restriction patterns were observed among the different cytoplasms, regardless of the restriction enzymes used. Figure 1 shows the uniform RFLP profiles of plants when the 19.4-kb chloroplast-specific probe of tomato $(\mathrm{P}-4)$ was hybridized to total DNA. Hybridization with the other three cpDNA probes also failed to uncover any polymorphisms (data not shown). Similarly, no variation in cpDNA was observed in any of the interspecific and intraspecific crosses.

A large degree of restriction fragment length polymorphism was observed across the mtDNAs of Vaccinium when digested with DraI, HindIII, AvaI, MspI, and RsaI, and probed with pZmEI (Table 1, Figs. 2 and 3). Analysis of tetraploid cultivars using the pZmEI probe uncovered several mtDNA types with DraI and HindIII restriction enzymes. Interestingly, 'Rubel' contained different fragment lengths than 'Bluecrop and 'Jersey', indicating that 'Bluecrop' and 'Jersey' do not carry 'Rubel' cytoplasm as their pedigrees imply (Hancock and Krebs, 1986). Our data are insufficient to determine the true maternal parent of these two cultivars.

When DNAs of interspecific hybrids and intraspecific hybrids were digested with DraI and HindIII and analyzed using pZmEI, they all displayed phenotypes identical to the female parent, indicating maternal inheritance of mtDNA (Fig. 4).

Our analysis of cpDNA of selected Vac'cinium taxa revealed that the chloroplast genome has undergone little nucleotide change in the portion of the genome examined. This mirrors numerous other studies in plants (Palmer, 1985). It is possible that the chloroplast genome in Vaccinium first differentiated at the diploid level and has not changed after polyploidization and speciation. A similar situation was postulated in rice (Oryza 'sativa L.) (Ogihara and Tsunewaki, 1988). Blueberry species that we did not evaluate may exhibit variability in their cpDNA. Ho'saka and Hanneman (1988) found uniform 'cpDNA types in both the common and Chil lean potatoes (Solanum tuberosum ssp. tub'erosum) even though the proposed progenitor, 1 the Andean potatoes (Solanum tuberosum ssp. 'andigena), the South American tuber-bear$\mathrm{j}_{\text {ing }}$ species, contained diverse patterns of 'cpDNA variation.

In contrast to cpDNA, the mitochondrial genome appears to have undergone substantial change. Similar patterns have been ob'served in many other angiosperms. Lonsdale (1984) suggested that the mtDNA of plants $i_{\text {is larger and less stable than cpDNA because }}$ $t_{\text {the more repetitive mtDNA may promote re- }}$ 
combination and the alteration of restriction patterns. It has also been suggested that the inverted repeat found in most plastomes may suppress recombinations or that plastome mutations may be corrected by gene conversions (for review see Palmer, 1985).

The large amounts of variation observed in the mtDNA of Vaccinium indicate that breeders fortuitously selected variable cytoplasms in creating highbush cultivars. This is not surprising, since three divergent species at two ploidy levels are represented. It is not known if these DNA variations translate into functional differences, but the high degree of mtDNA variability among the different cytoplasmic sources suggest that RFLPs should provide useful information on the evolution and taxonomy of the group. Nuclear RFLPs should also aid in locating economically important traits through the development of linkage maps.

\section{Literature Cited}

Ballington, J.R. 1990. Germplasm resources available to meet future needs for blueberry cultivar improvement. Fruit Var. J. 44:54-63.

Draper, A.D., J.R. Ballington, and G.J. Galletta. 1982. Breeding methods for improving southern tetraploid blueberries. J. Amer. Soc. Hort. Sci. 107:106-109.

Fox, T.D. and C.J. Leaver. 1981. The Zea mays mitochondrial gene coding cytochrome oxidase subunit II has an intervening sequence and does not contain TGA codons. Cell 26:315-323.

Hancock, J. and S. Krebs. 1986. Cytoplasms of highbush blueberry cultivars. Fruit Var. J. 40:4950

Hancock, J.F. and J.H. Siefker. 1986. Levels of inbreeding in highbush blueberry cultivars. HortScience 17:363-366.

Helentjaris, T., G. King, M. Slocum, C. Siedenstrang, and S. Wegman. 1985. Restriction frag ment polymorphisms as probes for plant diversity and their development as tool for applied plant breeding. Plant Mol. Biol. 5:109-118.

Helentjaris, T., M. Slocum, S. Wright, A. Schaefer, and J. Nienhuis. 1986. Construction of genetic linkage maps in maize and tomato using restriction fragment length polymorphisms. Theor. Appl. Genet. 72:761-769.

Hosaka, K. and R.F. Hanneman, Jr. 1988. The origin of the cultivated tetraploid potato based on chloroplast DNA. Theor. Appl. Genet. 76:172-176

Ichikawa, H., L. Tanno-Svenaga, and J. Imamura. 1989. Mitochondrial genome diversity among cultivars of Daucus carota (ssp. sativus) and their wild relatives. Theor. Appl. Genet. 77:39-43.

Landry, B.S., R.V. Kesseli, B. Farrara, and R.W. Michelmore. 1987. A genetic map of lettuce (Lactuca sativa L.) with restriction fragment length polymorphism, isozyme, disease resistance and morphological markers. Genetics 116:331-337

Lonsdale, D.M. 1984. A review of the structure and organization of the mitochondrial genome of higher plants. Plant Mol. Biol. 3:201-206.

Levings, C.S., III, and D.R. Pring. 1976. Restriction endonuclease analysis of mitochondrial DNA from normal and Texas cytoplasmic male-sterile maize. Science 193:158-160.

Lyrene, P.M. 1990. Low-chill highbush blueberries. Fruit Var. J. 44:82-87.

Maniatis, T., E.F. Fritsche, and J. Sambrook. 1982 Molecular cloning-A laboratory manual. Cold
Spring Harbor Laboratory Press, Cold Spring Harbor, N.Y.

Ogihara. Y. and K. Tsunewaki. 1988. Diversitv and evolution of chloroplast DNA in Triticum and Aegilops as revealed by restriction fragment analysis. Theor. Appl. Genet. 76:321-332.

Osborn, T.C., D.C. Alexander, and J.F. Fobes. 1987. Identification of restriction fragment length polymorphism linked to genes controlling soluble solids content in tomato fruit. Theor. Appl. Genet. 73:350-356.

Palmer. J.D. 1985. Comparative organization of chloroplast genomes. Annu. Rev. Genet. 19:325354.

Phillips, A.L. 1985. Restriction map and clone bank of tomato plastid DNA. Current Genet. 10:147-152.

Rogers, S.O. and A.J. Bendich. 1985. Extraction of DNA from milligram amounts of fresh. herbarium and mummified plant tissue. Plant Mol. Biol. 5:69-76.

Schumann, C. and J. Hancock. 1989. Paternal inheritance of plastids in alfalfa. Theor. Appl. Genet. 78:863-866.

Southern, E.M. 1975. Detection of specific sequences among DNA fragments separated by gel electrophoresis. J. Mol. Biol. 98:503-517.

Thomashow, M.F., V.C. Knauf, and E.W. Nester. 1981. Relationship between the limited and wide host range octopine-type $\mathrm{Ti}$ plasmids of Agrobacterium tumefaciens. J. Bacterial. 146:484-493.

Timothy, D.H., C.W. Levings, III, D.R. Pring, M.F. Conde. and J.L. Kermickle. 1979. Organelle DNA variation and systematic relationships in the genus Zea: Teosinte. Proc. Natl. Acad. Sci. USA 76:4220-4224.

Wagner, D.B., G.R. Furnier, M.A. Saghai-Maroof, S.M. Williams, B.P. Dancik, and R.W. Allard. 1987. Chloroplast DNA polymorphisms in lodgepole and Jack pines and their hybrids. Proc. Natl. Acad. Sci. USA 84:2097-2100.

Weissinger, A.K., D.H. Timothy, C.S. Leving, III, and M.M. Goodman. 1983. Pattern of mitochondrial DNA variation in indigenous maize races of Latin America. Genetics 10:365-379.

Wight, C.P., D.T. Dennis, and R.H. Lau. 1986 A rapid and efficient method to remove labeled molecular probes from nucleic acids immobilized on solid supports. Mol. Biol. Rpt. 11:173175.

HORTSCIENCE 27(1):47-50. 1992.

\section{Spontaneous Tetraploid Melons}

\section{Perry E. Nugent}

U. S. Vegetable Laboratory, Agricultural Research Service, U. S. Department of Agriculture, Charleston, SC 29414

\section{Dennis T. Ray ${ }^{2}$}

Department of Plant Sciences, University of Arizona, Tucson, AZ 85721

Additional index words. muskmelon, cantaloupe, Cucumis melo, polyploidy, virescent marker, diploid, triploid, seedless melons

Abstract. Since 1968, three spontaneous 4x melons (Cucumis melo L.) plants were discovered in our field or greenhouse plantings. Two were found in the cultivar Planters Jumbo and one in the virescent marker C879-52. Each of these $4 x$ plants had rounded cotyledons, shorter internodes, thicker stems and leaves, more hairs, and smaller fruits, with larger stem and blossom scars, than their $2 x$ counterparts. Also, their flowers, pollen grains, stomates, and seeds were larger. The discovery of a $4 x$ virescent plant in 1987 allows easier germplasm transfer between ploidy levels. Morphological characteristics of $2 x$ and $4 x$ melons will allow identification without need for chromosome counts.

Interest in tetraploid $(4 \mathrm{x}=48$ chromosomes) melons began in the 1930s with the discovery that colchicine produced polyploid plants. Shifriss (1942) began developing tetraploids of Cucumis sativus L. with colchicine in 1939 and then produced tetraploids of C. melo L. Batra (1952) developed six 4x melon cultivars with colchicine. Fruit quality in these tetraploids was superior to diploids ( $2 \mathrm{x}=24$ chromosomes); however, yields were lower in five of the six $4 \mathrm{x}$ lines. The $4 \mathrm{x}$ plants had larger flowers, pollen grains,

Received for publication 10 Dec. 1990. The cost of publishing this paper was defrayed in part by the payment of page charges. Under postal regulations, this paper therefore must be hereby marked advertisement solely to indicate this fact.

${ }^{1}$ Research Horticulturist.

${ }^{2}$ Assistant Professor. and stomates in addition to thicker stems and lower fertility than the $2 \mathrm{x}$ plants. Tetraploid fruit were smaller and rounder than diploid fruit. Kubicki (1962) developed 4x cucumbers and melons and stated that spontaneous 4x types were lacking in the genus Cucumis. Dumas de Vaulx (1974) induced 4x with colchicine, studied fertility, and confirmed the morphological characteristics described by previous workers. He found that pollen tube growth was normal and did not cause poor seed set in self-pollinated $4 \mathrm{x}$ or crosses between $2 \mathrm{x}$ and $4 \mathrm{x}$ plants. A few viable seeds were obtained when the $4 \mathrm{x}$ parent was female and none when it was male. Ervin (1941) studied polysomaty in C. melo. He found that $4 \mathrm{x}$ cells occur regularly in root and stem tips of most plants. This finding suggested that polysomaty may also occur in gametes and that spontaneous $4 \mathrm{x}$ plants might be 